\title{
PHOTOSYNTHETIC BEHAVIOUR DURING THE LEAF ONTOGENY OF RUBBER TREE CLONES [Hevea brasiliensis (Wild. ex. Adr. de Juss.) Muell. Arg.], IN LAVRAS, MG ${ }^{1}$
}

\author{
Comportamento fotossintético durante a ontogenia foliar de clones de seringueira, \\ [Hevea brasiliensis (Wild. ex. Adr. de Juss.) Muell. Arg.], em Lavras, MG
}

\author{
Aurélio Antas Miguel², Luiz Edson Mota de Oliveira ${ }^{3}$, Paulo Araquém Ramos Cairo ${ }^{4}$, \\ Davi Melo de Oliveira ${ }^{5}$
}

\begin{abstract}
This work proposed to investigate changes in the photosynthetic behavior during the leaf ontogeny of the during the leaf development. Up to the $32^{\text {nd }}$ day of leaf age (stage B2), the net photosynthesis was negative due to the inefficiency of the photosynthetic system, and this fact was justified by the following factors: low chlorophyll content, less stomatal conductance, high rubber tree clones PB 235, RRIM 600 and GT 1, in Lavras, MG. The experiment was performed in 2004, between May and July, under field conditions, at the Universidade Federal de Lavras. During the leaf ontogeny, the following characteristics were evaluated: chlorophyll content, gaseous exchanges and chlorophyll fluorescence. The clones presented similar profiles of alterations in the physiological characteristics internal $\mathrm{CO}_{2}$ levels and low chlorophyll fluorescence. From the $37^{\text {th }}$ day of leaf age, net photosynthesis became positive and gradually higher, stimulated by the increases in the chlorophyll contents, photochemical efficiency of photosystem II, carboxylation efficiency, stomatal conductance, transpiration and water use efficiency. Among the clones, photosynthetic behavior was similar, reaching maximum performance on the $57^{\text {th }}$ day of leaf age (stage D), when clone RRIM 600 showed the highest net photosynthesis, differing from the clones PB 235 and GT 1.
\end{abstract}

Index terms: Rubber tree, photosynthesis, gaseous exchanges, chlorophyll fluorescence.

\section{RESUMO}

Este trabalho, propôs-se a investigar mudanças no comportamento fotossintético durante a ontogenia foliar dos clones de seringueira PB 235, RRIM 600 e GT 1, em Lavras, MG. O experimento foi realizado no período de maio a julho de 2004, em condições de campo, na Universidade Federal de Lavras. Durante a ontogenia foliar avaliaram-se as seguintes características: os teores de clorofilas, as trocas gasosas e a fluorescência da clorofila. Os clones apresentaram perfis semelhantes de alterações nas características fisiológicas avaliadas durante o desenvolvimento foliar. Até o $32^{\circ}$ dia de idade foliar (estádio B2), a fotossíntese líquida foi negativa, devido à ineficiência do sistema fotossintético, sendo esta justificada pelos seguintes fatores: reduzidos teores de clorofilas, menor condutância estomática, alta concentração interna de $\mathrm{CO}_{2}$ e baixa fluorescência de clorofilas. A partir do $37^{\circ}$ dia de idade foliar, a fotossíntese líquida tornou-se positiva e gradativamente maior, estimulada por aumentos nos teores de clorofilas, eficiência fotoquímica do fotossistema II, eficiência de carboxilação, condutância estomática, transpiração e eficiência no uso da água. Entre os clones, o comportamento fotossintético foi semelhante, atingindo desempenho máximo no $57^{\circ}$ dia de idade foliar (estádio D), quando o clone RRIM 600 apresentou a maior taxa de fotossíntese líquida diferenciando-se significativamente dos clones PB 235 e GT 1.

Termos para indexação: Seringueira, fotossíntese, trocas gasosas, fluorescência da clorofila.

(Recebido para publicação em 22 de dezembro de 2005 e aprovado em 18 de abril de 2006)

\section{INTRODUCTION}

The studies on leaf ontogeny of rubber tree, relative to $\mathrm{CO}_{2}$ balance, have been accomplished predominately in greenhouse (Bergonci, 1981; Pita, 1984; Schwob et al., 1998). Under field conditions, such information is scarce. Studies have shown that leaf maturity of rubber tree is reached around 35 to 40 days after leaf emergence. In addition to phytohormonal equilibrium, leaf maturity can be regarded in terms of $\mathrm{CO}_{2}$ balance (Samsuddin \& Impens, 1979), and this, in turn, results into a series of characteristics, such as leaf expansion, chlorophyll accumulation, photosynthetic apparatus formation (photosystems I and II and caboxylative enzymes), stomata, cell wall and supporting structures. The knowledge about rubber tree phenological behavior is specially relevant when one intends to determine the required time to start leaf net photosynthesis. Under the

\footnotetext{
${ }^{1}$ Parte da tese do primeiro autor, apresentada à Universidade Federal de Lavras/UFLA - Cx. P. 3037 - 37200-000 - Lavras, MG, como parte das exigências para obtenção do grau de "doutor" em agronomia/fisiologia vegetal.

${ }^{2}$ Dr. em Fisiologia Vegetal - Universidade Federal de Lavras/UFLA - Rua: Aberto Pacheco, 120 - Apto. 202 - Ramos - $36570-000$ - Viçosa, MG aurelioantas@bol.com.br

${ }^{3}$ Professor Titular do Departamento de Biologia da Universidade Federal de Lavras/UFLA - Cx. P. 3037 - $37200-000$ - Lavras, MG - Pesquisador $1 \mathrm{C} / \mathrm{CNPq}$ - ledson@ufla.br

${ }^{4}$ Professor Assistente da Universidade Estadual do Sudoeste da Bahia/UESB - pcairo@uol.com.br

${ }^{5}$ Estudante de Engenharia Agronômica - Bolsista PIBIC-CNPq/UFLA - dmoagro@yahoo.com.br
} 
standpoint of yield, when this stage is reached, occurs the begining of assimilates accumulation, and it can support high growth rate in storage organs.

The highest net photosynthesis rates were found by Bergonci (1981) in leaves of young rubber plants which stomata conductance to $\mathrm{CO}_{2}$ was maximized on 40 days after leaf emergence. In young leaves (ten days), total photosynthesis rates were higher, due to high respiration rates, whereas net photosynthesis was negative or null, possibly, accounted for by low activity of Rubisco.

The dry matter increase in rubber tree leaves is directly related to the balance between $\mathrm{CO}_{2}$ assimilation, from photosynthesis, and its release, by respiration. During the juvenile phase, the $\mathrm{CO}_{2}$ balance in rubber tree is specially affected by respiration, which is significantly higher in this phase. The high respiration rates that occur in the juvenile phase seems to indicate a high metabolic activity (growth respiration), which energy released is required to the synthesis of structural compounds and chlorophyll, as well as to the maintenance of formed compounds (maintenance respiration). To reach net photosynthesis, the young leaves need to increase concentration of $\mathrm{CO}_{2}$, presenting thus a high $\mathrm{CO}_{2}$ compensation point in this phase (Bergonci, 1981). In young plants of malaysian rubber tree clones, grown in nutrient solution, Samsuddin \& Impens (1979) found that the maximum net photosynthesis rate occurred at $34^{\text {th }}$ day of leaf age (D stage).

In rubber plants, Lima (1998) noted a drop at the variable fluorescence / maximum fluorescence (Fv / Fm) ratio $(0.76)$ at noon, resulting from the reduction of the values of Fm, without any variations in initial fluorescence (Fo). The stability in Fo values suggests selective disturbances at the reaction centres of photosystem II (PSII), since the effects on the antennas would modify, simultaneously, the range of Fm and Fo. The decrease of Fm, without any changes in Fo, should be related the increases in thermal energy dissipation by inactive reaction centres of PSII (Van Wijk \& Krause, 1991). This behaviour can be associated with an adaptation in response to high temperature and radiation, which preserves the photosynthetic rates even under decrease of the Fv / Fm ratio (Lima, 1998).

The effects on plants, caused by variations in the environmental factors, occur in response to the alterations in the photosynthetic apparatus and or in the gas flux. These responses show differences among the species and, probably, they are distinct in the developmental phases of the leaf formation. In addition, several processes which have internal control modify the photosynthetic activity in a number of parts of the same leaf (Cavalcante \& Conforto, 2002).

The present work proposed to investigate changes in the photosynthetic behavior during leaf ontogeny of rubber tree clones PB 235, RRIM 600 e GT 1, in the period from May to June, in Lavras, MG.

\section{MATERIAL AND METHODS}

The experiment was accomplished in the period from May $6^{\text {th }}$ to June $6^{\text {th }}$ of 2004 , under field conditions, in the experimental area of the Plant Physiology Sector of the Universidade Federal de Lavras (UFLA), Lavras, MG. For the leaf ontogeny of rubber tree study, the treatments were five developmental stages (A, B1, B2, C e D) and three clones (PB 235, RRIM 600 e GT 1). The plants were chosen in a clonal garden and they were clipped at $90 \mathrm{~cm}$ up from the ground, for the monitoring since the beginning of the development of the germination of the vegetative buds.

For the study of ontogeny, daily observations were performed in the five stages of leaf development (A, B1, $\mathrm{B} 2, \mathrm{C}$ and D). The monitoring and the identification of these stages were done according to previous report by Hallé et al. (1978).

The evaluations were accomplished for 57 days, with six days interval from stage A to B1, and five days intervals during the development of the stages B2, C and $\mathrm{D}(0,6,12,17,22,27,32,37,42,47,52$ and 57 days). The observations were fulfilled from bud sprouting emergence, which were chosen and labeled when it reached about 2 $\mathrm{cm}$ in length, immediately after the formation of the first leaf primordia (stage A). The data of chlorophyll contents, gaseous exchanges and chlorophyll fluorescence were obtained from the mean of four replicates, in which each experimental plot was made up by two plants.

The measurements of chlorophyll contents in leaves of the rubber clones were performed during the experimental period, from stage A until stage D $(6,12,17$, $22,27,32,37,42,47,52$ and 57 days). The analyses were accomplished both in buds and leaves collected from sproutings previously selected and tagged in the same time and in the same plants in which the other variables were determined, according to the monitoring of their development. Chlorophyll concentrations were determined according to the methodology of Arnon (1949).

The evaluations of gaseous exchanges were done from the final of stage B2 $(32,37,42,47,52$ and 57 days) 
until stage $\mathrm{D}$, when the leaflets were with the size and conditions of being evaluated. Those evaluations were accomplished in the same plants in which chlorophyll fluorescence measurements were performed. Gaseous exchanges were measured in intact leaves by utilizing the infrared gas analyzer (IRGA), open system, portable, LCA-4 model (Hoddesdon, UK). The chlorophyll fluorescence evaluations were accomplished from stage B2 (17, 22, 27, 32, 37, 42, 47, 52 and 57 days) until stage $\mathrm{D}$, when the leaflets were with size and conditions of being evaluated. The photochemical efficiency of photosystem II was evaluated by utilizing a PEA fluorometer (Plant Efficiency Analyser, Hansatech, King 's Lynn, Norkfolk, $U K)$. Both chlorophyll fluorescence and gaseous exchanges evaluations were done on clear days, at 10 $\mathrm{h}$ (solar time).

\section{RESULTS AND DISCUSSION}

The chlorophylls $a, b$ and total content, and $a / b$ ratio, during the dry period, increased for the different clones, with leaf age (Figure 1). That behavior is similar to observed by Pita (1984), in researchs performed with two rubber tree species, $H$. brasiliensis Muell. Arg and $H$. pauciflora Muell. Arg., as well as the one verified by Bergonci (1981), in plants of clone Fx 2261.

The chlorophyll accumulation in leaves, during the ontogeny, occurred in two distinct phases (Figure 1). In the first phase, which extends until the $37^{\text {th }}$ day, the chlorophyll $a / b$ ratio showed a decline, up to a value around 1.0 (between 17 and 22 days of leaf age), increasing significantly from this period until the $37^{\text {th }}$ day of leaf age (Figure 1d). The highest values of the chlorophyll $a / b$ ratio pointed out a faster formation of chlorophylls $a$ than $b$. In the second phase, started after the $37^{\text {th }}$ day, the chlorophyll content was doubled, although the chlorophyll $a / b$ ratio, among the clones, has been maintained, which suggests that the increases in chlorophylls $a$ and $b$ contents, in this phase, occured in a similar way. During this phase, the contents of chlorophylls $a$ (Figure 1a), $b$ (Figure 1b) and total (Figure 1) continued increasing until the $57^{\text {th }}$ day, when the leaves maturity were fully reached.

The Figure 1 shows a marked increase in the contents of chlorophylls $a, b$ and total, from stage A to the $22^{\text {nd }}$ day (stage B2), when a reduction in these contents took place, remaining more or less constant until the $37^{\text {th }}$ day (stage $\mathrm{C}$ ). That reduction in the contents of chlorophylls $a, b$ and total, occurred in the clones, in the period between stages $\mathrm{B} 2$ and $\mathrm{C}$, concomitantly with the stage of highest leaf expansion. According to Samsuddin \& Impens (1979), the chlorophylls content decrease, during the phase of leaf expansion, is due to a dilution of these pigments, for the leaf expansion rate is faster than the chlorophyll synthesis rate.

The total chlorophyll content in leaves of clone RRIM 600 has shown higher levels than the others clones (Figure 1c), from the $42^{\text {nd }}$ day to the $57^{\text {th }}$ day of the leaf age. The difference can be due to distinct behaviors of photosynthesis of those clones.

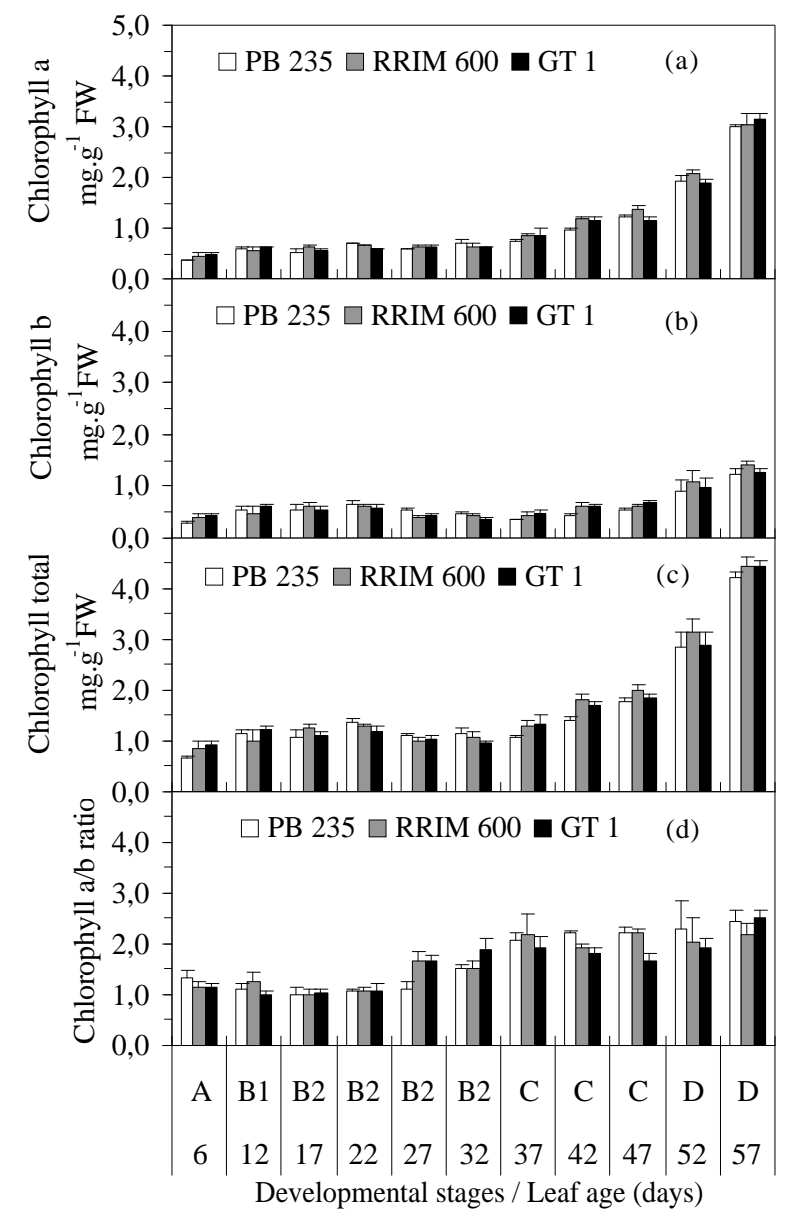

FIGURE 1 - Contents of chlorophylls $a$ (a), $b$ (b), total (c) and $a / b$ ratio (d), during leaf ontogeny of rubber tree clones in the dry season in Lavras, MG, 2004. The bars in each column indicate standard error of the mean of four replicates. 
The values relating to gaseous exchanges of clones PB 235, RRIM 600 and GT 1, during leaf ontogeny in the dry period, are presented in Figures 2 and 3. During the leaf growth, there were increases in stomatal conductance (Figure 2d), net photosynthesis (Figure 3a), water use efficiency (Figure 2b), carboxylation efficiency (Figure 2c) and transpiration (Figure 3d), whilst the internal $\mathrm{CO}_{2}$ concentration decreased until the $42^{\text {nd }}$ day of leaf age, remaining practically constant among the clones, after that period, until the leaf maturity (Figure 2c). Possibly, from this age, there was increased internal $\mathrm{CO}_{2}$ assimilation by leaves, which presented themselves more developed. Both density of photosynthetically active photon flux (DPAPF) and leaf temperature presented similar behaviors, during the leaf development (Figures 2a and 2b).

In general, clone GT 1 showed higher leaf temperature (Figure 2b), as well as elevated transpiration (Figure $3 \mathrm{~d}$ ) from the $42^{\text {nd }}$ day of leaf age, which may have caused decreases in water use efficiency and lower net photosynthesis of this clone in relation to clones PB 235 and RRIM 600 (Figures 3a e 3b). Clone RRIM 600 presented the highest net photosynthesis rates throughout the periods of the evaluations distinguishing markedly from clones PB 235 and GT 1 in the end of stage D (Figure 3a). The net photosynthesis increase was also followed by an augment in stomatal conductance (Figure 3d), with values significantly higher between the $52^{\text {nd }}$ and $57^{\text {th }}$ day of leaf age (stage d), when the leaves were fully expanded and mature.

In Figure 3a, it is found that net photosynthesis was negative on the $32^{\text {nd }}$ day (stage $\mathrm{B} 2$ ), becoming positive since the $37^{\text {th }}$ day (stage $C$ ). These results suggest that during the period lasted between stages A and late B2, the leaf operates as a strong sink, utilizing stored reserves in the stem and photoassimilates produced by mature leaves. The poor photosynthetic rates in early leaf ontogeny and the high ones at the end, are associated with some characteristics, such as high stomatal resistance, elevated respiration (Samsuddin \& Impens, 1979; Pita, 1984; Schwob et al., 1998) and high $\mathrm{CO}_{2}$ compensating point (Bergonci, 1981), which occur in early leaf formation. However, other characteristics, such as dry matter accumulation, leaf area, chlorophylls content (Bergonci, 1981; Pita, 1984) and stomatal conductance (Schwob et al., 1998), increased with the development, reaching maximum values with leaf maturity. It is likely that, in the present work, the combinations among these parameters have contributed toward increased net photosynthesis, water use efficiency and carboxylation efficiency of different clones.
The negative values of net photosynthesis can be related to low chlorophyll contents found in the leaves, at stage B2 (Figure 1) and, possibly, also to a low Rubisco activity in these young leaves. These observations agree with the results obtained by Dickmann (1971) in young leaves of Populus deltoides Marsh., who found small amounts of pigments and low activity of the $\mathrm{CO}_{2}$ assimilating enzyme, in comparison to adult leaves. For Bergonci (1981), during leaf ontogeny of clone $\mathrm{Fx} 2261, \mathrm{CO}_{2}$ assimilation presents physical limitations, such as stomatal resistance and biochemical limitations, such as chlorophyll content and enzyme activity in $\mathrm{CO}_{2}$ reduction.

Bergonci (1981) verified that both highest net photosynthesis rates and stomatal conductance to $\mathrm{CO}_{2}$ were found in fully expanded leaves of clone Fx 2261 (stage D). On the other hand, in young leaves of stage B2, net photosynthesis was negative or null, with relatively low stomatal conductance relative to the adult ones, suggesting that the latter depends, mainly, on the transformation of pre-stomatal cells into functional stomata during leaf development. Based in these results, it is possible to, in the present work, the stomata were not yet fully formed in stage B2, which can account for the low stomatal conductance and absence of positive net photosynthesis (Figures 2d and 3a).

Only from the $47^{\text {th }}$ day, when the leaves were fully expanded, the net photosynthesis began to increase significantly, along with the chlorophyll contents (Figure 1), carboxylation efficiency and water use efficiency. This is a consequence also from the higher values of stomatal conductance (Figure 3). One can infer that during leaf ontogeny these characteristics practically do not differ among the clones during that dry and cold season, but differences in these characteristics may occur among the clones, in other seasons of the year, as in the rainy season.

Figure 4 illustrates the results of early $(\mathrm{Fo})$ and maximum chlorophyll fluorescence (Fm), and variable / maximum chlorophyll fluorescence ( $\mathrm{Fv} / \mathrm{Fm}$ ) ratio. It is found that there was an increase of these variables with leaf development. Nevertheless, from the $37^{\text {th }}$ day, F0 began to reduce (Figures 4a), whereas Fm continued increasing (Figure 4b) until the $47^{\text {th }}$ day, reducing somewhat, soon afterwards. This implies greater increase in $\mathrm{Fv}$, considering that $\mathrm{Fv}=\mathrm{Fm}-\mathrm{F} 0$ and, hence, increase at the $\mathrm{Fv} / \mathrm{Fm}$ ratio (Figure 4c) and greater production of quantum of the photochemical in the clones studied, after this period.

Ciênc. agrotec., Lavras, v. 31, n. 1, p. 91-97, jan./fev., 2007 
The highest values of Fv / Fm ratio on the $47^{\text {th }}$ day (Figure 4c) coincide with the greatest leaf development, the significant rises of chlorophyll contents (Figure 1) and the greatest values of net photosynthesis (Figure 3a) in the clones researched, in the same period. That suggests that the photosynthetic apparatus (photosystems I and II

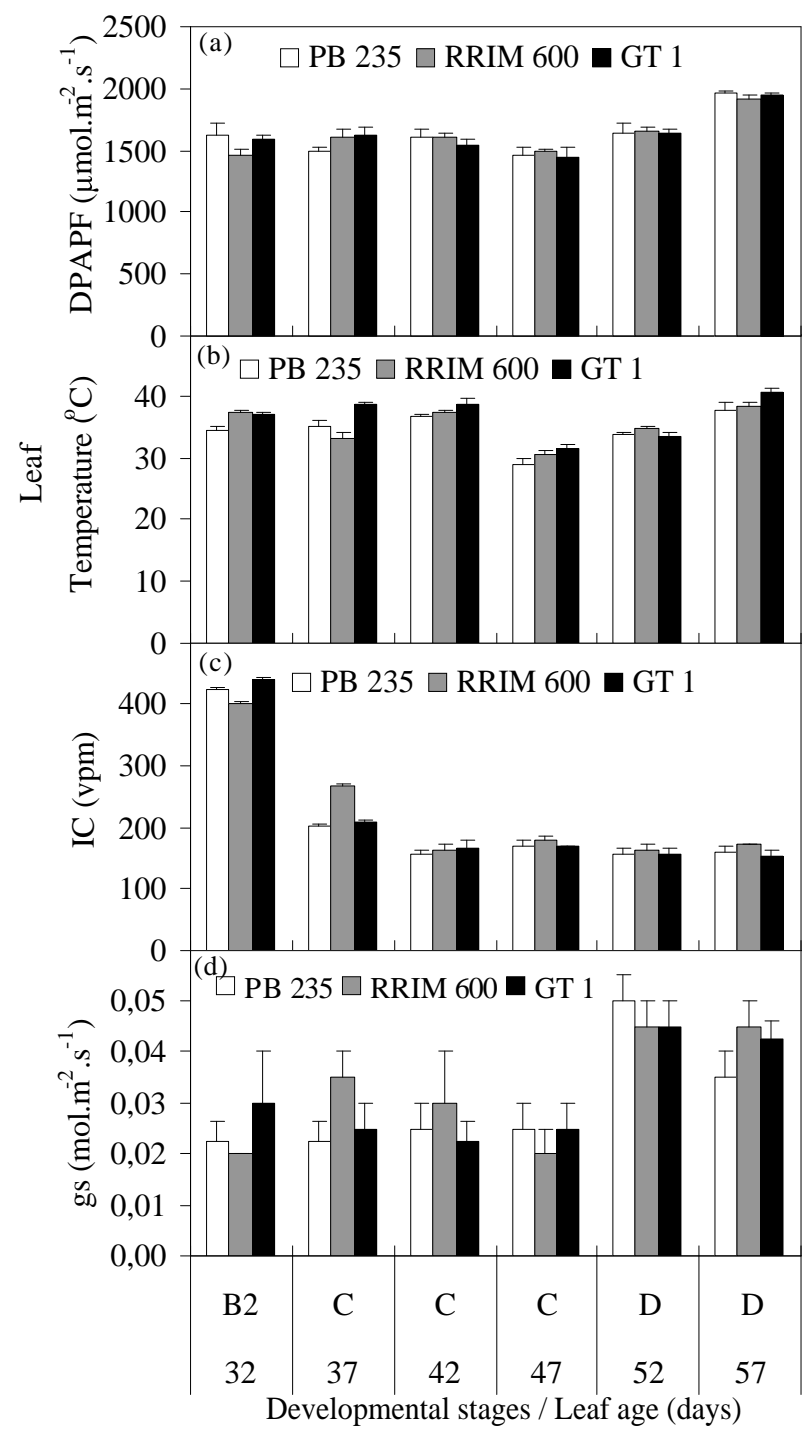

FIGURE 2 - Density of photosynthetically active photons flux (DPAPF) (a), leaf temperature (b), internal $\mathrm{CO}_{2}$ concentration (IC) (c) and stomatal conductance (d) during leaf ontogeny of rubber tree clones, in the dry season, in Lavras, MG, 2004. The bars in each column indicate standard error of the mean of four replicates. and carboxilative enzymes) were already completely formed. In general, clone RRIM 600 presented the highest values of the Fv / Fm ratio (Figure 4c) during leaf ontogeny, as compared with clones PB 235 and GT 1. That also reverberated on the chlorophyll contents (Figure 1) and net photosynthesis (Figure 3a).

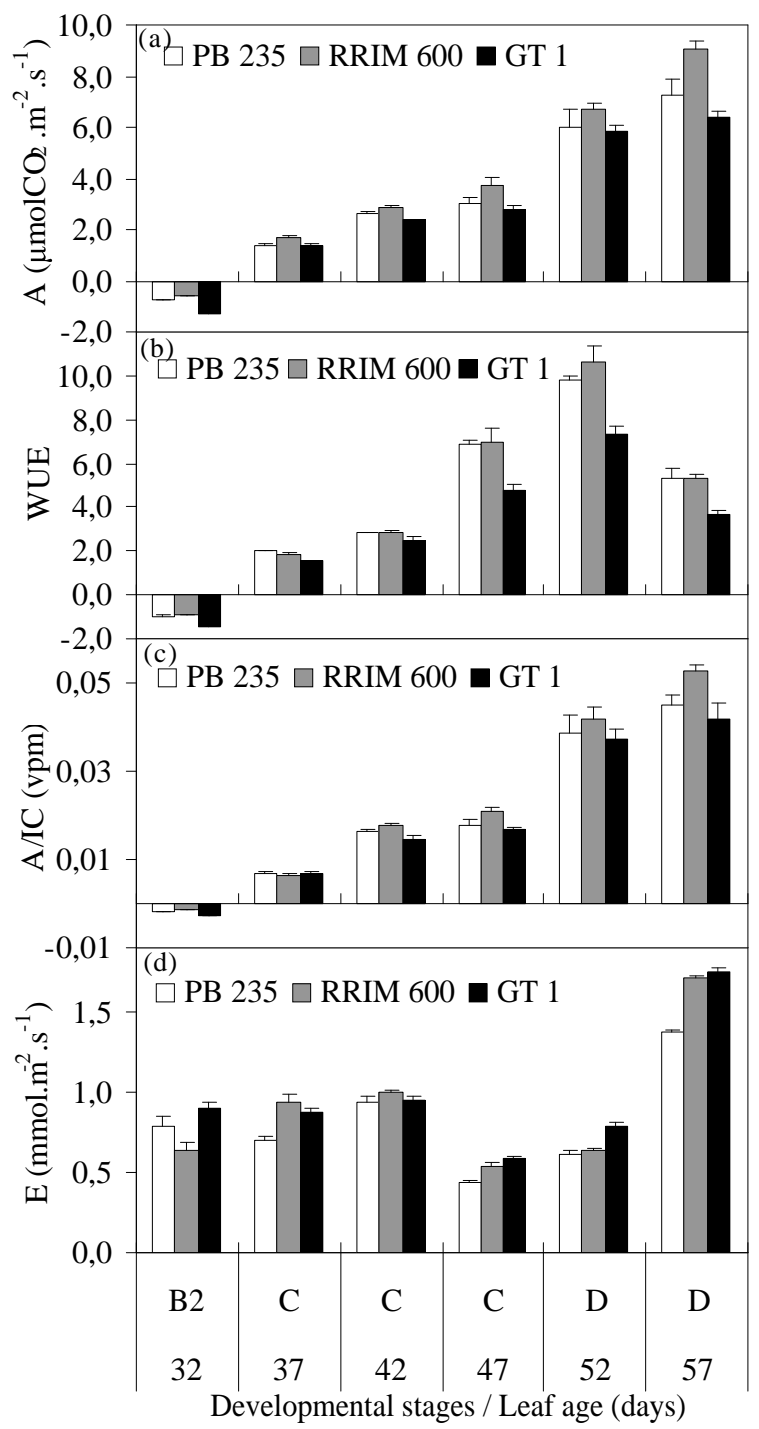

FIGURE 3 - Net photosynthesis (A) (a), water use efficiency (WUE) (b), carboxilation efficiency (A/IC) (c) and transpiration (E) (d) during leaf ontogeny of rubber tree clones, in the dry season, in Lavras, MG, 2004. The bars in each column indicate standard error of the mean of four replicates. 


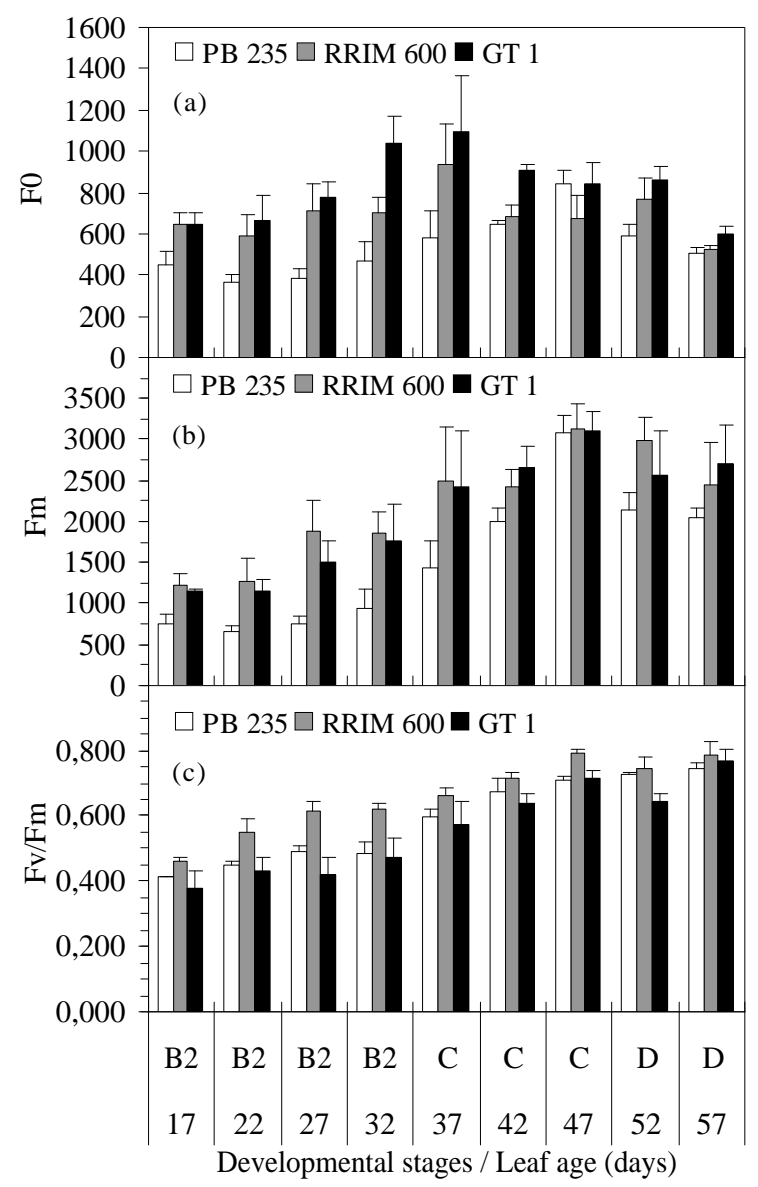

FIGURE 4 - Early (a) and maximum (b) chlorophyll fluorescence, and variation of chlorophyll fluorescence based in Fv / Fm ratio (c), during leaf ontogeny of rubber tree clones, in the dry season, in Lavras, MG, 2004. The bars in each column indicate the standard error of the mean of four replicates.

The Fv / Fm ratio is regarded as the measure of using radiant energy absorbed in photosynthesis. Thus, elevated values of this ratio, in mature laves, imply an improvement in the utilization of absorbed radiant energy and intensification of the Calvin cycle reactions. The results of $\mathrm{Fv} / \mathrm{Fm}$ ratio, presented in Figure $4 \mathrm{c}$, confirm that in stage $\mathrm{D}$ the leaf photosynthetic apparatus of the rubber clones, here studied, possibly were fully formed. For a great variety of species, the $\mathrm{Fv} / \mathrm{Fm}$ ratio ranges from 0.800 to 0.833 (Björkman \& Demmig, 1987). In the present wok, even when the photosynthetic apparatus was completely formed, the clones presented, in stage $\mathrm{D}$, values of $\mathrm{Fv}$ / Fm ratio somewhat lower than (Figure 4c) that ones showed in other publications, which may be associated with the influences of low temperatures and dry period during the experimental evaluations.

Noormets et al. (2001) investigated the behavior of young, newly mature, mature and old leaves, during the development of Populus tremuloides Michx. Clones. They found a low content of Rubisco and reduced rate of net photosynthesis in young leaves. The results obtained in the present work suggest that, likely, in early leaf ontogeny of the rubber clones (Figure 4 ), there were limitations in uptake and utilization of radiant energy produced by the photochemical step in the Calvin cycle reactions. In stage D $\left(57^{\text {th }}\right.$ day $)$, when the leaves were fully expanded and mature, clones PB 235, RRIM 600 and GT 1 showed values of FV / Fm ratio correspondent to $0.75,0.79$ and 0.77 , respectively. Those values were similar to the results found by Senevirathna et al. (2003) in fully expanded leaves of rubber tree cultivated under field conditions. The lowest values of Fv / Fm ratio presented by clone GT 1 , possibly are due to a greater increase of Fo relative to Fm, which implicates reduction of Fv.

\section{CONCLUSIONS}

Based in the physiological alterations, and their effects upon photosynthetic behavior of plants during leaf ontogeny, one can conclude that:

- Clones PB 235, RRIM 600 and GT 1 presented similar alterations in physiological characteristics during leaf ontogeny;

- Chlorophyll contents increased during leaf ontogeny, and the highest intensity ocurred between stages C e D;

- Until the $32^{\text {nd }}$ day of leaf age (stage B2), there were negative net photosynthesis, low chlorophylls content, high internal $\mathrm{CO}_{2}$ concentration, low stomatal conductance and chlorophyll fluorescence;

- From the $37^{\text {th }}$ day of leaf age, net photosynthesis became positive and gradually higher, its also being followed by increases of chlorophylls content, photochemical efficiency of photosystem II, carboxylation efficiency, stomatal conductance, transpiration and water use efficiency;

- The photosynthetic behavior was similar among the clones, reaching maximum performance at $57^{\text {th }}$ day of the leaf age (stage D). 


\section{BIBLIOGRAPHICAL REFERENCES}

ARNON, D. I. Copper enzymes in isolated chloroplasts. Polyphenoloxidase in Beta vulgaris. Plant Physiology, Amsterdam, v. 24, n. 1, p. 1-15, Jan. 1949.

BERGONCI, J. I. Estudos ecofisiológicos relacionados com o balanço de $\mathrm{CO}_{2}$ durante a ontogenia foliar em (Hevea brasiliensis Müell. Arg.). 1981. 53 p. Dissertação (Mestrado em Fisiologia Vegetal) - Universidade Federal de Viçosa, Viçosa, MG.

BJÖRKMAN, O.; DEMMIG, B. Photon yield of $\mathrm{O}_{2}$ evolution and chlorophyll fluorescence characteristics at $77 \mathrm{~K}$ among vascular plants of diverse origins. Planta, New York, v. 170, n. 2, p. 489-504, June 1987.

CAVALCANTE, J. R.; CONFORTO, E. C. Desempenho de cinco clones jovens de seringueira na região do Planalto Ocidental paulista. Bragantia, Campinas, v. 61, n. 3, p. 237 245, 2002.

DICKMANN, D. I. Chlorophyll, ribulose-1,5-diphosphate carboxilase, and Hill reaction activity in developing leaves of Populus deltoides. Plant Physiology, Rockville, v. 48, n. 2, p. 143-145, Aug. 1971.

HALLÉ, F.; OLDEMAN, R. A.; TOMLINSON, P. B. Tropical trees and forest. Berlim: Springer-Verlag, 1978. $441 \mathrm{p}$.

LIMA, D. U. Avaliação sazonal da produção e do metabolismo do carbono e nitrogênio em plantas de seringueira (Hevea brasiliensis Muell. Arg.) cultivadas em Lavras, Minas Gerais. 1998. 71 p. Dissertação (Mestrado em Fisiologia Vegetal) - Universidade Federal de Lavras, Lavras, MG.
NOORMETS, A.; SÔBER, A.; PELL, E. J.; DICKSON, R. E.; PODILA, G. K.; SÔBER, J.; ISEBRANDS, J. G.; KARNOSKY, D. F. Stomatal and non-stomatal limitation to photosynthesis in two trembling aspen (Populus tremuloides Michx.) clones exposed to elevated $\mathrm{CO}_{2}$ and/ or $\mathrm{O}_{3}$. Plant, Cell and Environment, Oxford, v. 24, n. 3, p. 327-336, Mar. 2001.

PITA, F. A. O. Ontogenia foliar em plântulas de seringueira (Hevea spp.) submetidas a dois regimes hídricos. 1984. 92 p. Dissertação (Mestrado em Fisiologia Vegetal) - Universidade Federal de Viçosa, Viçosa, MG.

SAMSUDDIN, Z.; IMPENS, I. The development of photosynthetic rates with leaf age in Hevea brasiliensis Muell. Arg. clonal seedlings. Photosynthetica, Prague, v. 13, n. 3, p. 267-270, 1979.

SCHWOB, I.; DUCHER, M.; SALLANON, H.; COUDRET, A. Growth and gas exchange responses of Hevea brasiliensis seedlings to inoculation with Glomus mosseae. Trees - Structure and Function, New York, v. 12, n. 4, p. 236-240, Feb. 1998.

SENEVIRATHNA, A. M. W. K.; STIRLING, C. M.; RODRIGO, V. H. L. Growth, photosynthetic performance and shade adaptation of rubber (Hevea brasiliensis) grown in natural shade. Tree Physiology, Victoria, v. 23, n. 10, p. 705-712, July 2003.

VAN WIJK, K. J.; KRAUSE, G. H. Oxygen dependence of photoinhibition at low temperature in intact protoplasts of Valerianella locusta L. Planta, New York, n. 1, p. 135-142, 1991. 